\title{
Mentoring and coaching in promoting publications in the Department of Physiotherapy at a local university in South Africa
}

\begin{abstract}
A growing shift towards research and evidence based practice in academia is associated with requirements to disseminate research results in the form of publication in peer reviewed journals. Mentoring has been identified as an important component of developing young authors, as it increases confidence and competence, and facilitates professional development. This led to the formation of a support group to stimulate peer-review publication in the physiotherapy department at the University of the Western Cape. The Kirkpatrick Framework of Evaluation was used to evaluate the success of the mentoring process which made use of a participatory action research methodology. The writing group consisted of nine academic members of staff and took place over ten weeks. The programme included writing, giving feedback, discussion and peer review on a weekly basis. Focus group discussions were taped and transcribed in order to evaluate the mentoring process by identifying relationships within the data and categorising key concepts, which were shaped into a thematic framework. The findings indicated that participants experienced a variety of emotions throughout the programme, with an overall feeling of personal growth by the end. In addition, participants also reported improved writing, reviewing and communication skills. Six months following the programme, six participants had submitted at least one article to a peer reviewed journal. It is clear from this study that some academics still find the task of writing and reviewing articles daunting, and that guidance and support in the form of a writing programme can be useful.
\end{abstract}

\section{KEY WORDS: MENTORING, PUBLICATION, ACADEMICS.}

\section{Introduction}

As more physiotherapy clinicians move into academia, there is a local and international shift towards research and evidence based practice (Frantz, 2007). The role of academics in physiotherapy is expanding beyond clinical training and teaching to include research and publication. Publishing research and clinical findings assists health professionals to contribute to the field of allied health, which will ultimately improve patient care. There is thus a need to support young academics in this paradigm shift from clinical work to research and publication. Many obstacles have been identified that contribute to difficulties with writing and publishing, including time constraints and poor writing skills (Cumbie et al, 2005; Rhoda et al, 2006). Together with the other activities required in the academic domain of physiotherapy, teaching and clinical supervision may also take precedence over the importance of academic publication.

Louw et al (2007) highlighted a need for mentoring in the area of research in physiotherapy departments at universities in the Western Cape in South Africa. Defined as "an interactive, interpersonal process between a group of experts and newcomers" (Goran, 2001:120), mentoring may help to build and maintain a professional network among academic and clinical staff, increase competence and confidence in publishing and reviewing articles, and allow for professional development. Allen, McManus and Russell (1999) indicated that group mentoring can result in successful socialization and improvement of work performance related to research. It can also facilitate creative research ideas (Emerson and Records,2005). However, no matter how creative the research is, it is almost useless unless the results are disseminated through publication. Pololi, Knight and Dunn (2004) have indicated that publishing is essential to furthering an academic career, and that offering a writing for publication programme in "a collaborative, peer mentoring effort, can facilitate knowledge, skills and support" needed to be productive in publishing.
Correspondence to:
Prof JM Frantz
Department of Physiotherapy
University of the Western Cape
Private Bag x17
Bellville
7530
Email: jfrantz@uwc.ac.za 
Emden (1998) highlighted that publishing in peer reviewed journals is an instrumental component in succeeding as a researcher. Productivity at this level will not only assist the academic with career advancement (Jones \& Gold, 1998) but will also improve the standing of the department within the university and discipline (Baldwin \& Chandler, 2002). This form of scholarly activity highlights the need to be open to, and accept constructive criticism or feedback through the process of peer review.

With this motivation to develop the skills necessary to critique articles and the goal for each academic to publish at least one peer-reviewed article per year at the University of the Western Cape (UWC), the Department of Physiotherapy formed a support group to encourage and stimulate academic publication. The Kirkpatrick Framework of Evaluation was used to evaluate the success of the mentoring process (Kirkpatrick, 1998). This framework consists of four levels, namely:

- Level 1: Participant reaction (evaluation of the participant's reaction to the intervention and its content)

- Level 2: Participant learning (evaluation of the extent to which participants acquired the knowledge, skills and abilities during the intervention)

- Level 3: Transfer of knowledge (extent to which the participant transferred information learnt into the job performance)

- Level 4: Productivity gains (the impact of the training programme on the department/organization)

\section{Methodology}

The study utilised a participatory action research methodology. According to MacIsaac (1995), action research has four cycles, namely planning, acting, observing and reflecting. This is further structured by Susman (1983), who highlights the five stages of action research. The application to this study is demonstrated in figure 1 .

The participants in the study were staff in the Physiotherapy Department at the University of the Western Cape who participated in a mentoring and support group for publication. The group consisted of nine academic staff members of whom two were male and seven were female. The mentoring and support programme took place over ten weeks and was dedicated to writing, feedback, discussion and reviewing. The programme objectives would allow participants to write various sections of an article as well as provide and receive feedback from critical readers. The aim of the mentoring and support process was to build and maintain a professional network among staff, increase competence and confidence in academic writing and reviewing articles, and facilitate the writing process through peer collaboration and feedback. Specifically the workshop helped participants gain knowledge and skills related to writing and reviewing the various components of an article. To incorporate the various levels of the Kirkpatrick Framework (Table 1), level 1 was achieved on a weekly basis where participants had the opportunity to share their opinion about the process as well as their feelings and thoughts about the programme. Comments from all participants were recorded and a summary of each session was made on a weekly basis, highlighting the main ideas. Level 2 was achieved through informal questioning by the facilitator after the sessions regarding the knowledge gained and the practical application on a weekly basis through writing of the various sections. Level 3 was achieved during focus group discussions that were held in week 8 to review the process as well as a questionnaire to determine the experiences of the participants and how they had practically implemented the knowledge gained. Level 4 was achieved by a questionnaire that was administered to the group 6 months after the intervention. The questionnaire was based on questions from a similar one used by McLean and Moss (2003).

Focus group discussions were conducted to evaluate the mentoring process. The information gathered for the focus groupdiscussions was tape recorded and transcribed verbatim. Information was then circulated to all participants for clarification and participants had to colour code similar thoughts and ideas. These codes were compared across the responses to identify relations within the data and to categorise key concepts, which were then shaped into a thematic framework. The identified themes were discussed by the group until consensus was reached. All themes are presented with quotes to ensure the trustworthiness of the information provided. Information from the questionnaires was captured on Excel and descriptively analysed.

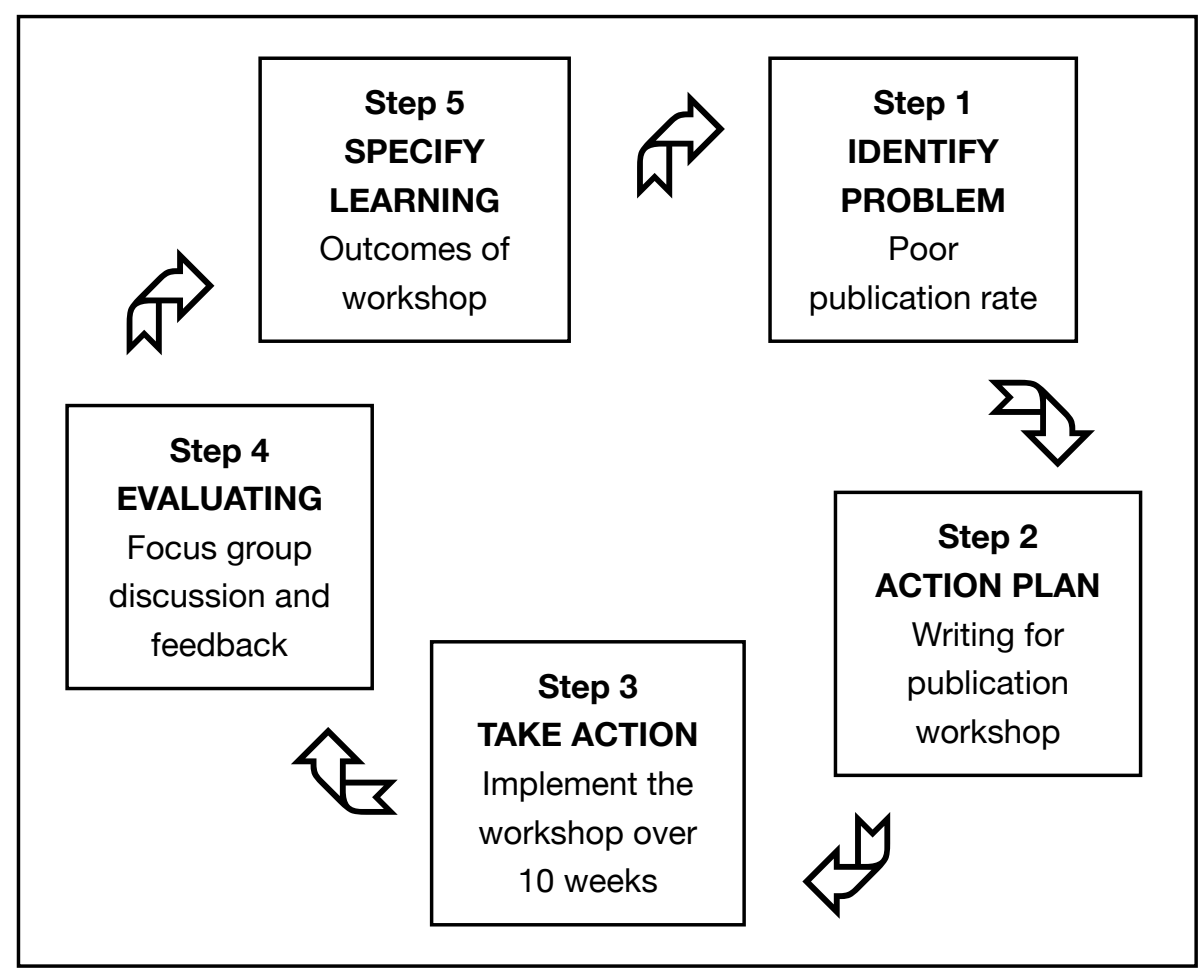

Figure 1: Steps involved in Action Research (Susman, 1983) 
Table 1: Evaluation Framework for the Writing for Publication workshop

\begin{tabular}{|l|l|l|l|l|}
\hline Evaluation Component & Level 1 & Level 2 & Level 3 & Level 4 \\
\hline $\begin{array}{l}\text { Weekly feedback sessions } \\
\text { inviting reflection on aspects } \\
\text { of the experience }\end{array}$ & $\sqrt{ }$ & $\sqrt{ }$ & & \\
\hline $\begin{array}{l}\text { Focus group discussion at end } \\
\text { of intervention focusing on } \\
\text { competence and evaluation } \\
\text { of the process }\end{array}$ & & $\sqrt{ }$ & $\sqrt{ }$ & $\sqrt{ }$ \\
\hline $\begin{array}{l}\text { Questionnaire at 3 months } \\
\text { focused on important } \\
\text { lessons learnt and practical } \\
\text { applications }\end{array}$ & $\sqrt{ }$ & $\sqrt{ }$ & $\sqrt{ }$ & $\sqrt{ }$ \\
\hline $\begin{array}{l}\text { Questionnaire at 6 months } \\
\text { focused on number of } \\
\text { manuscripts submitted and } \\
\text { reviewed }\end{array}$ & & & & $\sqrt{ }$ \\
\hline
\end{tabular}

Table 2 below outlines the programme for each week. Commitment to active participation in the group was obtained fromeachmemberatascheduledmeeting, and meetings were scheduled once a week for 2 hours each. The participants were purposively divided into two reviewer groups with each group having novice authors and established authors. Each participant was able to review a colleague's work within their group and this was done on a rotational basis and thus each participant acted as a critical reviewer for each group members' article. Participants also received feedback from other critical reviewers verbally and in writing . Opportunities were provided to evaluate the process after every session in order to determine the progress of

Table 2: Weekly programme

\begin{tabular}{|c|c|c|c|c|c|}
\hline Week 1 & Week 2 & Week 3 & Week 4-5 & Week 6-7 & Week 8-10 \\
\hline $\begin{array}{l}\text { Participants had } \\
\text { to have data from } \\
\text { research that } \\
\text { they would be } \\
\text { able to } \\
\text { work with }\end{array}$ & $\begin{array}{l}\text { Write an } \\
\text { introduction of } \\
500 \text { words }\end{array}$ & $\begin{array}{l}\text { Correct the } \\
\text { introduction } \\
\text { according to the } \\
\text { feedback given } \\
\text { and write the } \\
\text { methods and } \\
\text { results sections }\end{array}$ & $\begin{array}{l}\text { Correct the } \\
\text { introduction, } \\
\text { method and } \\
\text { results sections } \\
\text { according to } \\
\text { the feedback } \\
\text { given and write } \\
\text { the discussion } \\
\text { section }\end{array}$ & $\begin{array}{l}\text { Do all corrections } \\
\text { and write the } \\
\text { conclusion and } \\
\text { add references }\end{array}$ & $\begin{array}{l}\text { Do corrections } \\
\text { and finalize } \\
\text { the article with } \\
\text { the abstract } \\
\text { according } \\
\text { to authors } \\
\text { guidelines }\end{array}$ \\
\hline $\begin{array}{l}\text { Participants } \\
\text { had to identify } \\
\text { possible journals } \\
\text { and bring } \\
\text { the authors } \\
\text { guidelines for the } \\
\text { first meeting }\end{array}$ & $\begin{array}{l}\text { Submit the } \\
\text { introduction to a } \\
\text { critical reviewer } \\
\text { identified by the } \\
\text { facilitator in the } \\
\text { group }\end{array}$ & $\begin{array}{l}\text { Submit the } \\
\text { introduction, } \\
\text { methods and } \\
\text { results sections } \\
\text { to a new critical } \\
\text { reviewer in your } \\
\text { group }\end{array}$ & $\begin{array}{l}\text { Submit the } \\
\text { introduction to } \\
\text { discussion to } \\
\text { a new critical } \\
\text { reviewer in your } \\
\text { group }\end{array}$ & $\begin{array}{l}\text { Submit draft } 1 \text { of } \\
\text { the whole article } \\
\text { to a new critical } \\
\text { reviewer }\end{array}$ & $\begin{array}{l}\text { Submit draft } \\
2 \text { of the article } \\
\text { to the whole } \\
\text { group for } \\
\text { feedback }\end{array}$ \\
\hline $\begin{array}{l}\text { Supporting } \\
\text { articles were also } \\
\text { brought to this } \\
\text { meeting }\end{array}$ & $\begin{array}{l}\text { At the next } \\
\text { meeting, provide } \\
\text { verbal and } \\
\text { written feedback } \\
\text { to the person } \\
\text { for whom you } \\
\text { acted as a critical } \\
\text { reviewer }\end{array}$ & $\begin{array}{l}\text { At the next } \\
\text { meeting, provide } \\
\text { feedback to the } \\
\text { person for whom } \\
\text { you acted as a } \\
\text { critical reviewer }\end{array}$ & $\begin{array}{l}\text { At the next } \\
\text { meeting, provide } \\
\text { feedback to the } \\
\text { person for whom } \\
\text { you acted as a } \\
\text { critical reviewer }\end{array}$ & $\begin{array}{l}\text { At the next } \\
\text { meeting, provide } \\
\text { feedback to the } \\
\text { person for whom } \\
\text { you acted as a } \\
\text { critical reviewer }\end{array}$ & $\begin{array}{l}\text { At the next } \\
\text { meeting you } \\
\text { will receive } \\
\text { feedback from } \\
\text { more than one } \\
\text { critical reader }\end{array}$ \\
\hline $\begin{array}{l}\text { Participants } \\
\text { were then } \\
\text { informed about } \\
\text { the process, } \\
\text { expectations and } \\
\text { weekly outcomes }\end{array}$ & $\begin{array}{l}\text { You will receive } \\
\text { guidelines for } \\
\text { writing and } \\
\text { reviewing the } \\
\text { introduction in } \\
\text { your workshop } \\
\text { package }\end{array}$ & $\begin{array}{l}\text { You will receive } \\
\text { guidelines for } \\
\text { writing and } \\
\text { reviewing the } \\
\text { methods and } \\
\text { results section }\end{array}$ & $\begin{array}{l}\text { You will receive } \\
\text { guidelines for } \\
\text { writing and } \\
\text { reviewing the } \\
\text { discussion } \\
\text { section }\end{array}$ & $\begin{array}{l}\text { You will receive } \\
\text { guidelines for } \\
\text { writing and } \\
\text { reviewing the } \\
\text { conclusion and } \\
\text { the whole article }\end{array}$ & $\begin{array}{l}\text { You have now } \\
\text { been through } \\
\text { the process of } \\
\text { writing a draft } \\
\text { article and } \\
\text { reviewing } \\
\text { an article }\end{array}$ \\
\hline
\end{tabular}


each individual as well as the challenges they experienced. Discussion following this feedback was encouraged.

\section{Results}

A total of nine academics participated in the group. One of participants with an established publication record acted as the facilitator for the workshop. Of the nine participants, eight participated in the workshop and the ninth participant focused on analyzing the information obtained at different stages of the workshop. The demographic information of the group is presented in Table 3 below.
The main learning curves identified from the critical reader during the weekly feedback sessions included 7 key statements. Each statement is highlighted and presented with quotes (Table 4).

Information from the focus group discussion at the end of intervention was classified into information for level 2 and 3 of Kirkpatrick's Framework. The participants focused on their emotions, feelings and experiences, the process, group dynamics, feedback, skills and learning and finally outcomes. Areas are highlighted below and supported with quotes.

Table 3: Socio-demographic data

\begin{tabular}{|c|c|}
\hline Variables & $\mathbf{N}(\%)$ \\
\hline \multicolumn{2}{|l|}{ Gender } \\
\hline o Male & $2(22 \%)$ \\
\hline o Female & $7(78 \%)$ \\
\hline \multicolumn{2}{|l|}{ Age } \\
\hline o $\quad 30-40$ years & $6(67 \%)$ \\
\hline o $\quad 40-50$ years & $2(22 \%)$ \\
\hline $0>50$ years & $1(12 \%)$ \\
\hline \multicolumn{2}{|l|}{ Race } \\
\hline o Black & $1(12 \%)$ \\
\hline o White & $3(33 \%)$ \\
\hline o Coloured & $5(55 \%)$ \\
\hline \multicolumn{2}{|l|}{ Higher Degrees } \\
\hline o Masters & $6(67 \%)$ \\
\hline o $\quad$ PhD & $3(33 \%)$ \\
\hline \multicolumn{2}{|l|}{ Professional Status } \\
\hline Lecturer & $5(55 \%)$ \\
\hline Senior Lecturer & $1(12 \%)$ \\
\hline Associate Professor & $3(33 \%)$ \\
\hline \multicolumn{2}{|l|}{ Areas of interest } \\
\hline Disability and rehabilitation & $2(22 \%)$ \\
\hline Quality of life and Health promotion & $2(22 \%)$ \\
\hline Disease prevention & $4(44 \%)$ \\
\hline Education & $1(12 \%)$ \\
\hline \multicolumn{2}{|l|}{ Participants publication record } \\
\hline Novice authors: <3 publications & $5(56 \%)$ \\
\hline Author with limited experience: 3-15 articles & $2(22 \%)$ \\
\hline Established author: $>15$ publications & $2(22 \%)$ \\
\hline
\end{tabular}

It was found that participants experienced a continuum of emotions at various stages of the process. The emotions and feelings expressed identified that participants had grown personally and within the group. Theinitialreportsof "worry", "fear", and "daunting task" translated into feelings of "motivation", encouragement" and excitement" by the end of the workshop.

"At the beginning of the process I had feelings of worry however I was also excited for the outcome"

The participants also emphasized that although the process was demanding, it was also useful because it was formalized and guided, which made the process very valuable.

"I found it a good process and the way it was structured is something that should be encouraged for the future."

"Since I don 't have much experience in academic publishing (or any publishing for that matter), going through the writing and reviewing process was a useful learning experience. The guidelines we received were absolutely essential to me for this."

On a personal level, participants found the process motivating and encouraging. The process also improved time management among the participants and it allowed the participants to focus on a specific outcome of an article. In addition, a dedicated time slot for writing was found to be valuable.

"The way it was structured allowed me to have time to focus on the outcome which is a publication"

"Having dedicated time set aside to write an article is really appreciated"

The participants highlighted learning skills related to writing (e.g. how to write an introduction with linking sentences between paragraphs) and reviewing of an article (e.g. reading for flow of the article and golden thread throughout i.e. ensuring that the message is consistent from the introduction to the discussion). They also learnt group work skills as well as written and verbal communication skills. In addition the participants learnt how to make concepts clearer.

"I learnt a lot about writing and reviewing an article"

"Reading someone else's article, helped me formulate my own and structure it better" 
They also had to learn to open themselves up to criticism and how to provide effective feedback.

"Fear of the critical reader's feedback but feedback was positive and in the process of learning I learnt a lot"

The participants also highlighted the value of the workshop as it related to outcomes. They were excited that at the end of the workshop they would have a draft article that had been reviewed by more than one critical reader. It was also mentioned that the knowledge and skills obtained would assist in addressing articles that had been rejected or returned for revision.

"I can also now tackle other articles that have been rejected with the skills I have learnt"

"I have had this article in mind and have found it difficult to write the article but the structure has guided it"

"All in all, not only was it a good learning experience in terms of writing and reviewing an article, but the result is a finished, peer-reviewed article almost ready for submission"

At the 3 month follow up, the participants were able to reflect on what they were satisfied with during the workshop and what they felt could be improved upon. They also reflected on the skills they had learned and the application of those skills in their academic work. The skills developed were also found to have practical application in other areas of their lives as well and were classified into four main areas, including:

Improved ability to write an academic article (5)

"I am able to interact on the subject of article writing and construction with more confidence"

Improved ability on reviewing academic writing (5)

“...This has resulted in me reading and reviewing of postgraduate student work more critically."

Improved ability to structure, organise and set goals (4) “...ability to structure and organize articles in progress in a more structured manner..."

Improved ability to provide feedback (3)

"Acting as a reviewer and giving feedback has improved as I'm more sensitive to the author receiving the feedback"

"I have also been able to improve the kind of feedback that I give my masters students"

Six months later each participant had increased their academic output by either submitting or reviewing an article. Of the participants involved in the workshop, six of the eight $(75 \%)$ had submitted at least one article to a peer reviewed journal. In addition, $50 \%$ of the participants had had an article published and 50\% had reviewed an article for a journal. Articles developed or finalized during the workshop were at different stages with three $(37.5 \%)$ still working on it, two (25\%) having submitted to a journal and awaiting feedback, two

Table 4: Learning curves identified

\begin{tabular}{|c|c|c|c|}
\hline No & Statement & Section & Quote \\
\hline 1 & $\begin{array}{l}\text { Start the article with an impact } \\
\text { sentence. }\end{array}$ & Introduction & $\begin{array}{l}\text { "What is the most important idea you want to highlight why } \\
\text { this study is important?" }\end{array}$ \\
\hline 2 & $\begin{array}{l}\text { Write each paragraph with } \\
\text { connecting sentences. }\end{array}$ & Introduction & $\begin{array}{l}\text { "The ideas must flow into one another from one paragraph } \\
\text { to another" }\end{array}$ \\
\hline 3 & $\begin{array}{l}\text { Make sure the reliability and } \\
\text { validity of instruments used } \\
\text { are clearly explained as well as } \\
\text { sampling procedure and results } \\
\text { of pilot studies }\end{array}$ & Methodology & $\begin{array}{l}\text { "When adapting a validated and reliable questionnaire it is } \\
\text { important that reliability is tested on the adapted version" }\end{array}$ \\
\hline 4 & $\begin{array}{l}\text { Present the results in an easy to } \\
\text { read manner and then discuss } \\
\text { the most important findings. }\end{array}$ & Results & $\begin{array}{l}\text { "You cannot present the results to address an objective like } \\
\text { in a thesis - this is an article with limited number of words } \\
\text { thus highlight the most important findings" }\end{array}$ \\
\hline 5 & $\begin{array}{l}\text { Make sure you are able to } \\
\text { highlight the importance of } \\
\text { your results in your discussion } \\
\text { thus answering the reader's "so } \\
\text { what?" question. }\end{array}$ & Discussion & $\begin{array}{l}\text { "At the end of the results section I want to say so what - the } \\
\text { impact of the findings is not highlighted strongly" }\end{array}$ \\
\hline 6 & $\begin{array}{l}\text { Making sure that the structure of } \\
\text { the article is balanced from the } \\
\text { introduction to the conclusion. }\end{array}$ & Conclusion & $\begin{array}{l}\text { "Your impact sentence at the beginning must have a } \\
\text { matching closing sentence in the conclusion" }\end{array}$ \\
\hline 7 & $\begin{array}{l}\text { It is important to write in a } \\
\text { manner that is easy for the } \\
\text { reader to understand. }\end{array}$ & General & $\begin{array}{l}\text { "You understand what you are saying but as a reader new } \\
\text { to this area, I find it difficult to understand what you are } \\
\text { trying to say" }\end{array}$ \\
\hline
\end{tabular}


(25\%) having submitted to journals, received feedback and were working on reviewer comments, and one (12.5\%) completed and ready for submission.

\section{Discussion}

Numerous studies have been conducted concerning improved publication rates for academics (Grant and Knowles, 2000; Lee and Boud, 2003; Pololi et al 2004). However, it is evident from this study that writing for publication is still seen as a daunting task and that the need for structure and guidance is needed, especially for novice authors. Various intervention strategies have been used to promote publication output with varied results (McGrail, Rickard and Jones, 2006). The most successful interventions depend on the participants and the objectives of the intervention. Structuring workshops, such as the one in the current study, enables academics to learn and to practice strategies that will assist them in writing articles. Murray and Newton (2008), suggest that writing for publication enhances clinical knowledge and practice and thus should be considered an important component in both academics' and clinicians' job descriptions. However, this task has been hampered by barriers such as a lack of time and the appropriate skills.

The current study emphasized that the structure of the programme and the dedicated time to write was valued. Kliewer (2005) reported that the first stages of writing an article can be challenging but if guided by a structured process, even junior staff can write a well organized article. Although the partcipants valued the availability of dedicated time they reported that the time between the feedback sessions was too short. They also recommended that time be set aside within the workshop period to make changes as recommended by the critical reader. In suggesting this the participants expressed that the workshops could be extended to take place over a full day. The pre-set time slot with the structure of the workshop had however been experienced as positive, as it assisted the participants to complete an article. Setting aside dedicated time was also identified by Rhoda et al. (2006) as an important factor when writing for publication. The participants in that study reported that setting aside specific time slots assisted in completing an article. The first few days during student vacations were also mentioned as a suitable time. Although academics are under pressure to publish they often prioritise teaching and administrative duties and finding the time to write is often a major challenge (Maurtin-Cairncross et al. 2005). Writing for publication workshops such as this one may encourage academics to write, as mandatory time slots are allocated.

Structured programmes for writing are usually aimed at assisting in the development of knowledge and skills related to writing. The participants in the current study indicated that they developed specific skills including: prioritising the need to publish and making time to write a section of the article every week; learning how to provide effective feedback through critically reviewing a colleague's work and communicating this through written and verbal feedback; learning how to open themselves to criticism and 'hearing' the positive and negative comments; making changes to their articles in response to reviewer feedback; and finally submitting the articles to a journal for publication. There was an increase in the understanding of the process of publication, as well as the requirements and culture of a particular journal that could assist them in increasing their publication output. This is similar to findings by Sommers et al. (1996), who indicated that knowledge and skills in writing and publication improved following the intervention. The specific skills developed included developing and clarifying concise purpose statements, also reported by Miller and Muhlenkamp (1989) cited in McGrail et al. (2006). Dies (1993) reported that some writers have a limited understanding of the writing and publication process and uncertainty about which ideas are worthy of publication. This finding was confirmed by the results in this study when participants reported that similar skills to those mentioned above were obtained. We need to be mindful of the fact that a lack of skills or a lack of confidence could be contributing factors to low publication rates. Previous researchers have also found that authors report a lack of confidence in their writing ability (Grant \& Knowles, 2000; Hale \& Pruiit, 1989), as well as a fear of rejection (Dies, 1993).

The current study also highlighted the value of the programme with feedback from critical readers but similarly demonstrated that there may be a negative reaction by participants to feedback. Rickard et al. (2008), highlighted that multiple researchers in a group with a variety of perspectives proved to be a strength. However, Grzybowski, Bates, Calam et al. (2003) reported that not all writers were comfortable with receiving feedback from fellow professionals. Even if feedback is given in a way that is intended to be constructive, it may be taken personally and viewed negatively. It is important for writers to be able to separate themselves from their articles, regardless of how much they have invested of themselves into the work. Feedback is intended to develop the article and not the person although by reflecting on the feedback, the author will develop, either professionally, personally or both.

This study demonstrates that writing for publication programmes can support academics in increasing their academic outputs and thus assist in improving their academic standing. It is in the best interest of the university if academics are publishing and thus opportunities such as this intervention should be created on a regular basis. Through this support programme, at least $75 \%$ of the participants were able to submit an article to a peer reviewed journal for consideration.

\section{Conclusion}

It is evident that although writing for publication is an important component of academia, some academics find the task daunting for a variety of reasons, and struggle to find the time to dedicate to writing. The results of this study highlight some of the challenges faced by new authors and critical readers, and suggest several means of overcoming these obstacles. The support and guidance obtained through participation in the writing group gave staff members a 
sense of confidence and facilitated the acquisition of new skills that will assist them in moving forward, both as authors and reviewers.

\section{References}

Allen T, McManus S, Russell J (1999). Newcomer socialization and stress. Formal peer relationships as a source of support. Journal of Vocational Behaviour 54: 453-470.

Baldwon C, Chandler G (2002). Improving faculty publication output: the role of a writing coach. Journal of Professional Nursing 18(1): 8-15.

Cumbie S, Cumbie C, Weinert S, Luparell V, Conley J, Smith J (2005). Developing a scholarship community. Journal of Nursing Scholarship 37(3): 289-293

Dies R (1993). Writing for publication: Overcoming common obstacles. International Journal of Group Psychotherapy 43(2): 243-249

Emden C (1998). Establishing a 'track record': Research productivity and nursing academia. Australian Journal of Advanced Nursing 16(1): 29-33

Emerson R, Records K (2005). Nursing profession in peril. Journal of Professional Nursing. 21(1): 9-15.
Frantz J(2007). Challenges facing physiotherapy education in Africa. The Internet Journal of Allied Health Sciences and Practice. 5(4): ISSN 1540-580x

Goran S (2001). Mentorship as a teaching strategy. Critical Care Nursing Clinics of North America 13 (1 ): 119-129

Grantz B, Knowles S (2000). Flights of imagination: academic women be(com)ing writers. International Journal for Academic Development 5(1): 6-19

Hale S, Pruitt R (1989). Enhancing publication success. Nursing Connections 2(1): 59-61

Jones R, Gold J (1998). Faculty appointment and tenure policies in medical schools: a 1997 status report. Academic Medicine 73: 212-219.

Kirkpatrick D (1998). Evaluating training programs: The four levels. San Francisco: BerrettKoehler.

Kliewer M (2005). Writing it up: A step-by-step guide to publication for beginning investigators. American Journal of Radiology. 185: 591-596.

Lee A, Boud D (2003). Writing groups, change and academic identity: research development as local practice. Studies in Higher Education 28(2): 187-200.

Louw Q, Grimmer-Somers K, Crous L, Marais M, Amosun S (2007). Framing a vision for physiotherapy research: synthesizing educators viewpoints in Cape Town. The Internet Journal of Allied Health Sciences and Practice. 5(2): ISSN 1540-580x
MacIsaac D (1995). An introduction to action research. Http://www.phy.nau.edu/ danmac/ actionresearch.html Accessed 08/09/09

McGrail M, Rickard C, Jones R (2006). Publish or perish: a systematic review of interventions to increase academic publication rates. Higher Education Research and Development 25(1): 19-35

McLean S, Moss G (2003). They're happy, but did they make a difference? Applying Kirkpatrick's framework to the evaluation of a national leadership program. The Canadian Journal of Program Evaluation 18(1): 1-23.

Miller B, Muhlenkamp A (1989). Teaching students how to publish in nursing journals: A group approach. Journal of Nursing Education. 28(8): 379-381

Murray R, Newton M (2008). Facilitating writing for publication. Physiotherapy. 94: 29-34.

Pololi L, Knight S, Dunn K (2004). Facilitating scholarly writing in Academic Medicine. Journal of Gen. Internal Medicine.19: 64-68

Rhoda A, Maurtin-Cairncross A, Phillips J, Witbooi S (2006). Conquering the publishing silences of black academic women. Journal of Community and Health Sciences. 1(2): 70-77.

Rickard C, McGrail M, Jones R, O’Meara, Robinson A, Burley M, Ray-Barruel G (2008). Supporting academic publication: Evaluation of a writing course combined with a writers' support group. Nurse Education Today. Doi: 10.1016/j. nedt.2008.11.005

Susman G (1983). Action Research: a sociotechnical systems perspective. Ed.G. Morgan. Sage Publications, London.

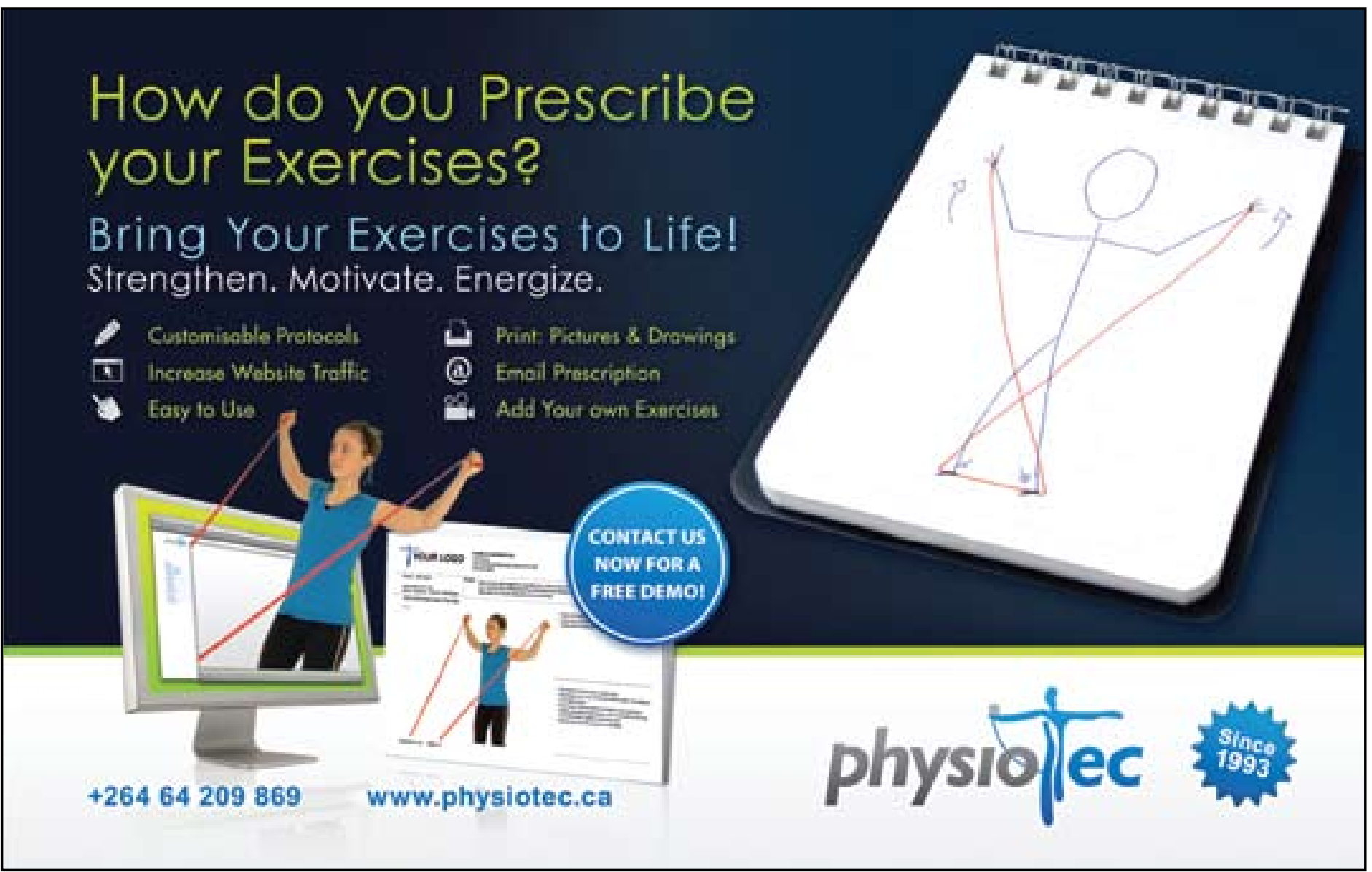

